\title{
Penggunaan kiasan dalam plot konflik filem: Satu analisis pragmatic
}

\author{
Metaphorical usage of conflict plot in film: A pragmatic approach \\ Aminnudin Saimon \\ aminnudin.saimon@yahoo.com \\ Zaitul Azma Zainon Hamzah \\ zazh@upm.edu.my \\ Universiti Putra Malaysia, Serdang, Selangor, Malaysia \\ DOI: https://doi.org/10.37134/pendeta.vol10.5.2019
}

\begin{abstract}
ABSTRAK
Bahasa kiasan merupakan satu bentuk bahasa yang diungkapkan bagi mengindahkan sesuatu perkara yang kurang elok atau mempunyai niat yang tidak elok. Pengungkapan bahasa kiasan dalam konflik ini mempunyai pelbagai tujuan, antaranya mengungkapkan ketidakpuasan hati, kekecewaan dan perkelahian. Sehubungan itu, tulisan ini bertujuan untuk menganalisis penggunaan bahasa kiasan dalam plot konflik menggunakan pendekatan pragmatik. Data diperoleh menerusi filem Melayu yang dilakonkan oleh Nordin Ahmad, iaitu Lanchang Kuning, Semerah Padi, Hang Jebat dan Seri Mersing. Hasil kajian mendapati bahasa kiasan banyak diungkapkan dalam plot konflik bagi menyatakan kekecewaan, perkelahian dan ketidakpuasan hati. Kajian ini juga membuktikan bahawa pengungkapan bahasa kiasan dapat difahami oleh komunikator berdasarkan pendekatan teori pragmatik. Kesimpulannya, penelitian terhadap bahasa dalam filem telah dapat menyerlahkan keperibadian, akal budi positif atau negatif dan kekreatifan masyarakat Melayu dalam menyampaikan sesuatu perkara dalam suasana konflik.
\end{abstract}

Kata kunci: Bahasa Kiasan, Konflik, Filem Melayu, Pendekatan Pragmatik

\begin{abstract}
Euphemism refers to a form of indirect language uttered to substitute words that are offensive or intended to become harsh. The use of euphemism in conflict serves several purposes; to express dissatisfaction, frustration and argumentation. This study is conducted to analyse the use of euphemism in plot conflict through the pragmatic approach. Data was obtained by analyzing the Malay film, Lanchang Kuning, Semerah Padi, Hang Jebat and Seri Mersing, acted by Nordin Ahmad. Findings suggest that euphemism was frequently used in plot conflict to express frustration, argument and dissatisfaction. This study also provides evidence that euphemistic expressions were understood by the communicator based on the pragmatic theory approach. In conclusion, observation on language use in film showed personality, positive and negative mind and creativity of the Malay community in delivering their intended meaning in conflict settings.
\end{abstract}

Keywords: Euphemism, conflict, Malay film, pragmatic approach

\section{PENGENALAN}

Bahasa digunakan oleh penuturnya untuk menyampaikan gagasan, buah fikiran dan perasaannya dalam pelbagai situasi dan tujuan komunikatif. Penggunaan bahasa dengan pelbagai strategi ini telah 
memperlihatkan nilai-nilai sosial dan kebudayaan yang diamalkan oleh sesebuah masyarakat. Corak dan bentuk sesuatu bahasa itu bergantung pada penutur yang menuturkannya dan dalam suasana bahasa tersebut digunakan. Salah satu strategi yang digunakan oleh masyarakat penutur untuk menyampaikan hajat komunikatif adalah melalui penggunaan bahasa kiasan. Pentafsiran bahasa kiasan menurut Awang Sariyan ialah bahasa kiasan seperti peribahasa mempunyai peranannya yang istimewa bukan sahaja memperkaya khazanah bahasa, bahkan lebih penting daripada itu dalam memancarkan pandangan hidup, nilai, sikap, cara berfikir dan kepekaan akal budi masyarakat pengguna bahasa itu sendiri. Penggunaan bahasa kiasan dalam komunikasi juga dapat memancarkan jati diri, keperibadian, tingkah laku dan kognitif di samping membawa kepada tafsiran akal budi.

Penggunaan bahasa kiasan dalam filem dilihat amat menarik untuk diikuti, malah penggunaannya dalam filem juga dapat menarik penonton, mempengaruhi minda, menyampaikan keintelektualan seseorang. Penggunaan bahasa kiasan bukan sahaja untuk menyampaikan sesuatu buah fikiran, tetapi penggunaannya juga dapat memperindah sesuatu plot terutamanya plot konflik dalam filem. Sesuatu filem yang menarik semestinya mempunyai plot untuk mengembangkan dan merungkai permasalahan yang diketengahkan. Sesuatu plot yang menarik dapat mempengaruhi emosi penonton, dan memberi kesan kepada penonton. Penggunaan bahasa kiasan dalam plot konflik dapat memperlihatkan budaya, bahasa, akal budi dan kelakuan penutur dalam mengungkapkan sesuatu perkara kepada pendengar. Penyampaian bahasa kiasan dalam sesuatu konflik dilihat mempunyai matlamat dan agenda yang hendak disampaikan di samping memperlihatkan keindahan budaya dan bahasa Melayu.

Sarjana seperti Nor Hashimah Jalaludin dan Zaitul Azma Zainon Hamzah lebih menumpukan pada kajian yang melibatkan komunikasi implikatur, peribahasa, kiasan, dan kesantunan. Kecenderungan ini disebabkan medium kajian yang pelbagai mengandungi ujaran-ujaran komunikatif yang disampaikan penutur kepada pendengar. Justeru itu, penyelidikan bahasa dalam filem dilihat tidak banyak diteroka terutamanya penyelidikan mengenai bahasa kiasan yang digunakan dalam plot konflik.

\section{PERMASALAHAN KAJIAN}

Pada peringkat awal, bahasa kiasan dikaji adalah untuk melihat kefahaman masyarakat Melayu mengenai peribahasa dan simpulan bahasa. Begitu juga dengan kajian-kajian sarjana yang memfokuskan kepada aspek peribahasa seperti 'Penginterpretasian Peribahasa dan Hubungan dengan Kemahiran Berfikir: Analisis Berdasarkan Teori Relevans' oleh Hasmidar Hassan dan Jafizah Jaafar (2016), aspek penciptaan iklan oleh Noraini Shahida Ishak dan Maschitah Mansor (2014) dalam 'Peribahasa: Gambaran Minda Melayu dalam Penciptaan Iklan' dan deria rasa dalam peribahasa oleh Nor Afiqah Wan Mansor dan Nor Hashimah Jalaluddin (2016) dalam 'Makna Implisit Bahasa Kiasan Melayu: Mempertalikan Komunikasi, Kognisi dan Semantik'.

Berdasarkan pemaparan kajian-kajian lepas yang dinyatakan dalam pengkajian mengenai bahasa kiasan, kajian yang dijalankan mempunyai kelompangan dari sudut bahan kajian. Kebanyakan sarjana banyak menggunakan medium peribahasa, simpulan bahasa, novel, dan hikayat, namun kajian yang mengkaji bahasa kiasan dalam filem tidak banyak diteroka lagi. Justeru dalam tulisan ini, pengkaji cuba membincangkan penggunaan bahasa kiasan dalam plot konflik yang terdapat dalam filem menggunakan pendekatan pragmatik.

Selain itu, pengkajian bahasa kiasan lebih menumpukan kepada makna tersirat dan memperoleh makna sebenar bahasa kiasan, namun pengkajian mengenai bahasa kiasan dalam konflik merupakan fenomena bahasa yang dilihat sebagai satu bentuk keunikan dalam masyarakat Melayu. Justeru, masalah yang timbul daripada kelompangan ini adalah kebanyakan kajian lebih menumpukan pemerolehan makna bahasa kiasan, namun kajian yang melihat penggunaan bahasa kiasan dalam plot konflik tidak banyak diteroka. Selain itu, permasalahan yang timbul daripada isu-isu ini juga memaparkan penggunaan bahasa untuk mencapai hubungan saling memahami dalam sesuatu konflik. Penzahiran penutur untuk menyampaikan rasa marah, benci, geram dan sebagainya disampaikan melalui maklumat linguistik dan 
diterima oleh pendengar. Sehubungan dengan ini, permasalahan yang timbul ialah maklumat linguistik yang disampaikan melalui ujaran kiasan sukar untuk difahami dan memerlukan kos yang tinggi.

\section{SOROTAN KAJIAN LEPAS}

Abd. Ganing Laengkang (2018) menjalankan penyelidikan yang bertajuk "Analisis Lakuan Bahasa Terhadap Teks Khutbah Jumaat Negeri Selangor" mendapati bahawa tiga kategori lakuan dan 13 subkategori sering digunakan dalam teks khutbah jumaat. Penyelidikan ini menggunakan pengkategorian Bach \& Harnish (1979) yang bertujuan untuk menganalisis lakuan bahasa terhadap teks khutbah jumaat yang diterbitkan oleh Jabatan Agama Islam Selangor (JAIS). Jumlah kekerapan yang didapati dalam teks khutbah jumaat adalah sebanyak 341 kekerapan. Lakuan bahasa yang paling kerap digunakan dalam teks khutbah jumaat ialah lakuan bahasa nasihat (83), lakuan deskriptif (61), lakuan makluman (42), dan lakuan penegasan (41). Penyelidikan ini menunjukkan bahawa khutbah jumaat bersifat nasihat dan deskriptif. Justeru itu, kajian yang dijalankan oleh sarjana ini mempunyai kelebihannya yang tersendiri, terutamanya dari sudut bidang penyelidikan yang dijalankan, iaitu menggunakan teks khutbah sebagai bahan kajian. Banyak kajian-kajian mengenai lakuan bahasa dijalankan seperti kajian antara budaya, sesi kaunseling, mesyuarat, namun kajian yang memperlihatkan sesuatu lakuan bahasa yang sudah tersedia seperti juga filem belum banyak diterokai.

Cerny (2017) menjalankan penyelidikan yang bertajuk "On The Function of Speech Acts in Doctor - Patient Communication" mendapati bahawa lakuan bahasa yang sering digunakan dalam komunikasi antara doktor dengan pesakit ialah lakuan pertanyaan, manakala lakuan yang paling kerap diujarkan oleh pendengar ialah lakuan asertif makluman. Dalam penyelidikan ini, beliau menggunakan Teori Lakuan Bahasa Searle (1969). Hasil daripada dapatan kajian, beliau merumuskan kepada lima kategori, iaitu penyataan, pertanyaan, jawapan, direktif dan reaktif. Selain itu, kebanyakan lakuan direktif pertanyaan yang digunakan merupakan bentuk pertanyaan tertutup yang mengehendaki pendengar menjawab menggunakan jawapan yang pendek, ringkas dan padat. Kajian yang dijalankan ini memberikan manfaat dalam penyelidikan yang dijalankan dari sudut dapatan kajian. Kajian yang dijalankan oleh sarjana ini mendapati bahawa lakuan bahasa yang diperoleh menggunakan ayat yang pendek, ringkas dan padat dalam menyampaikan sesuatu maklumat. Penggunaan ayat yang pendek, ringkas dan padat dapat membantu pendengar untuk memahami niat komunikatif penutur di samping dapat mengelakkan salah faham.

Penyelidikan yang bertajuk "How to Develop Appropriate Refusal Strategies" yang dijalankan oleh Zohreh Rasekh Eslami (2017) mendapati bahawa lakuan penolakan merupakan lakuan yang paling sukar untuk diujarkan dan kebiasaannya melibatkan pelbagai strategi untuk mengelakkan pendengar tersinggung oleh lakuan penolakan yang diujarkan. Penyelidikan yang dijalankan ini bertujuan untuk melihat penggunaan strategi penolakan dalam lakuan bahasa. Teori yang digunakan dalam penyelidikan ini menggunakan strategi penolakan Beebe et al (1990). Penyelidikan ini juga mendapati bahawa lakuan penolakan amat berjaya digunakan kepada pelajar yang mempelajari bahasa sebagai bahasa kedua. Hasil kajian mendapati bahawa strategi penolakan secara langsung sering digunakan dalam menolak sesuatu pelawaan, pertanyaan dan penyataan, manakala strategi penolakan secara tidak langsung digunakan dalam menolak pujian, pelawaan, ajakan dan penawaran. Dengan berbekalkan maklumat linguistik, lakuan penolakan berjaya dicapai yang memerlukan tahap kecekapan pragmatik yang tinggi berbanding matlamat bahasa sesuatu lakuan bahasa. Kesimpulan daripada penyelidikan ini menunjukkan bahawa lakuan penolakan digunakan untuk menolak pelawaan, undangan, penyataan dan sebagainya. Hasl daripada penyelidikan ini mendapati bahawa pengguna bahasa dapat memanfaatkan strategi yang digunakan dalam membuat penolakan.

Penyelidikan berkaitan dengan ujaran telah banyak dijalankan meliputi pelbagai sudut ilmu, persepsi dan budaya. Penyelidikan ujaran dari sudut pragmatik banyak dijalankan, antaranya penyelidikan yang dijalankan oleh Mohd. Aris Anis dan Ahmad Esa (2016) yang bertajuk Fungsi dan Peranan Komunikasi Berimplikatur dalam Budaya Masyarakat Melayu Islam mendapati bahawa penggunaan 
bahasa tersirat atau implikatur dalam komunikasi terpancar dalam pertuturan dan penulisan. Hasil dapatan kajian menunjukkan ujaran-ujaran yang dikaji menggunakan pelbagai jenis ayat untuk menyampaikan sesuatu maksud. Dalam dialog filem yang dikaji, implikatur ayat figuratif paling banyak digunakan dalam filem kenegaraan. Ayat jenis ini menyerapkan unsur-unsur kiasan, perumpamaan, bidalan, metafora, ironi dan sebagainya. Ujaran dalam dialog filem yang dikaji juga kurang menggunakan ayat interogatif (tanya). Ayat interogatif yang membawa maksud implikatur digunakan dalam perbualan yang mengandungi unsur keraguan dan ketidakpastian. Selain itu, ujaran orang Melayu juga selalunya diselitkan dengan unsurunsur peribahasa. Peribahasa sering digunakan oleh orang Melayu sebagai satu cara dalam ujaran untuk menyampaikan sesuatu maksud dalam nada implisit.

Sarjana pragmatik ada menjalankan penyelidikan mengenai bahasa kiasan, antaranya Abdul Basir Awang et, all (2016), Nor Afiqah Wan Mansor \& Nor Hashimah Jalaluddin (2015), Hawiyah Baba \& Nor Hashimah Jalaluddin (2015) dan Black (2000 \& 2003). Kajian kiasan oleh Black (2000) telah menghasilkan beberapa kajian berkisar simpulan bahasa Melayu. Kajian beliau yang bertajuk Figuration, Lexis and Cultural Resonance: A Corpus Based Study of Malay yang meneliti simpulan bahasa berdasarkan anggota manusia, iaitu mata dan kaki dan hubunngan kognitif dengan penuturnya. Dapatan kajian mendapati bahawa MATA ADALAH SUMBER seperti mata pencarian, mata air, manakala KAKI MENUNJUKKAN SESUATU YANG TIDAK BAIK seperti kaki judi, kaki botol dan kaki perempuan.

Selain itu, bahasa kiasan juga dijalankan melibatkan suku kaum, antaranya penyelidikan oleh Mohd. Rasdi Saamah (2011) yang bertajuk Alam dan Budaya dalam Bahasa Kiasan Bahasa Semai. Dapatan kajian mendapati bahawa kebanyakan bahasa kiasan yang terdapat dalam penggunaan bahasa masyarakat orang asli Semai adalah berasaskan alam dan budaya dalam ruang lingkup kehidupan dan pemikiran seharian masyarakat tersebut. Kajian ini dilihat amat penting untuk memberi pemahaman kepada msayarakat tentang seni berbahasa dalam bahasa serumpun, merapatkan jurang sosial dalam kalangan masyarakat dan membuka ruang kepada penyelidikan selanjutnya terhadap bahasa-bahasa natif atau bahasa sukuan.

Pengkajian mengenai bahasa kiasan tidak hanya melibatkan peribahasa atau bukan peribahasa, namun kajian mengenai bahasa kiasan dilihat lebih meluas yang juga melibatkan kontrastif antara bahasa. Kajian kontrastif antara bahasa dapat dilihat melalui kajian Abdul Basir Awang et, all (2016) yang bertajuk Tetenunan Kinayah Arab dan Kiasan Melayu: Suatu Analisis Kontrasti. Dapatan kajian ini mendapati bahawa unsur tetenunan ini perlu diperjelaskan sejelas-jelasnya agar dapat dibandingkan secara menyeluruh. Huraian ini meliputi hampir semua komponen utama bahasa yang terdiri daripada unsur leksis, semantik, morfologi, fonologi dan sintaksis. Dapatan kajian juga mendapati kewujudan persamaan dan perbezaan dalam unsur tetenunan semantik, leksis, sintaksis dan fonologi antara kinayah Arab dengan kiasan Melayu. persamaan unsur ini akan memudahkan pengguna kiasan Melayu memahami kinayah Arab, manakala perbezaannya akan menghasilkan sikap berhati-hati agar tidak berlaku salah faham berkaitan kinayah Arab.

Berdasarkan sorotan kajian yang dinyatakan, jelas sekali kajian bahasa kiasan meliputi pelbagai aspek seperti silang budaya (cross-cultural), bahasa natif dan peribahasa. Justeru itu, penginterpretasian bahasa kiasan memerlukan teori dan penjelasan yang jelas agar bahasa kiasan dapat difahami oleh komunikator.

\section{METODOLOGI KAJIAN}

Data utama dalam kajian ini ialah filem Melayu lakonan Nordin Ahmad. Filem yang dijadikan data utama ialah filem Semerah Padi (seterusnya FSP), filem Hang Jebat (FHJ), filem Seri Mersing (FSM) dan filem Lancang Kuning (FLK). Pemilihan filem yang dilakonkan oleh beliau adalah kerana kualiti dan penggunaan bahasanya yang indah dan berpengaruh. Pemilihan filem dibuat adalah antara tahun 1956 hingga 1962. Pada tahun 1956 menerusi FSP nama beliau kembali memuncak menerusi watak utama, iaitu watak Taruna. Pemilihan tahun $(1956$ - 1962) tersebut dibuat adalah kerana pada tahun tersebut nama beliau dan filem yang dilakonkan membuatkannya kembali bersinar dan memuncak. Daripada 19 
buah filem yang dilakonkan sepanjang tempoh tersebut, enam buah filem yang membuatkan namanya terus menyinar dan memberi kesan sehingga kini, iaitu FSP (1956), FHJ (1961), FSM (1961) dan FLK (1962). Pemilihan keempat-empat buah filem adalah berdasarkan sampel daripada populasi filem terkenal yang dilakonkannya dari tahun 1956 hingga 1962.

Penulis telah memfokuskan pemerolehan data, iaitu bahasa kiasan dalam plot konflik sama ada perkelahian, kekecewaan, pertengkaran dan perdebatan. Pemilihan data ini dibuat adalah berdasarkan ujaran semasa konflik akan mencerminkan keperibadian seseorang melalui bahasa yang digunakan. Plot konflik merupakan plot kemuncak sesebuah cerita yang akan menentukan kejayaan cerita yang hendak disampaikan (Hatta Azad Khan, 2014). Bahasa kiasan yang diperoleh daripada filem yang dikaji akan dianalisis menggunakan teori Relevans (seterusnya TR) (Sperber \& Wilson, 1986) dan teori lakuan bahasa (LB) (Searle, 1969). Oleh yang demikian, objektif kajian ini adalah untuk menganalisis penggunaan bahasa kiasan dalam plot konflik dalam filem Melayu menggunakan pendekatan pragmatik. Pemilihan data berdasarkan plot konflik yang menggunakan bahasa kiasan dilihat satu dapatan yang menarik terutamanya dalam kosa ilmu pragmatik. Pemilihan filem sebagai fokus kajian adalah kerana penglahiran idea, pandangan dan kritikan pengarah dijelmakan dalam filem menerusi kata-kata yang terdapat dalam dialog. Cerminan daripada filem merupakan realiti sebenar kehidupan masyarakat pada masa tersebut. Setiap ujaran yang dijelmakan merupakan realiti sebenar masyarakat yang diolah dan dipaparkan ke dalam filem.

\section{TEORI RELEVANS DAN TEORI LAKUAN BAHASA}

Prinsip relevans lebih menekankan bentuk komunikasi yang dapat difahami antara penutur dengan pendengar (Sperber \& Wilson, 1986). Penutur seharusnya dapat menjamin yang diperkatakan itu benarbenar relevan serta sesuai untuk difahami oleh pendengar. Penutur dapat memastikan yang diperkatakan itu mempunyai ciri-ciri relevans yang optimum. Relevans yang optimum bermaksud setiap ujaran itu mempunyai kesan konteks yang maksimum yang dapat dirumuskan dalam masa sesingkat. Dengan itu, konteks haruslah seimbang dengan masa memproses untuk menghasilkan kandungan maklumat yang diharapkan (Wong Shia Ho, 2014).

Semasa menyampaikan ujaran, penutur seharusnya bertanggungjawab untuk memastikan ujarannya mengandungi maklumat yang sama dengan perhatian pendengar. Hal ini demikian kerana pendengar akan memberikan perhatian yang relevan pada dirinya. Penutur haruslah memberikan maklumat yang relevan dengan penaakulan dan persepsi pendengar dengan memberikan andaian tambahan kepada persekitaran kognitif pendengar (Zaitul Azma Zainon Hamzah, 2011). Terdapat tiga konsep yang penting dalam TR dalam pentafsiran makna, iaitu konteks, kesan konteks dan usaha memproses.

Teori LB memperlihatkan bahawa bahasa yang dituturkan mempunyai lakuan bahasanya yang tersendiri. Pengertian asas dalam teori ini tertumpu kepada cara menghubungkan makna dan lakuan dengan bahasa. Pengertian ini bertepatan dengan hipotesis Searle (1969) yang mengatakan 'bercakap dengan sesuatu bahsa bererti menceburkan diri ke dalam satu bentuk perlakuan yang terikat dengan peraturan'. LB menekankan bahawa pengklasifikasian LB memainkan peranan penting dalam perlakuan komunikasi dan berdasarakan teori ini, komunikasi bukan sahaja bererti perlakuan bagi mendapatkan maksud pengucap, tetapi juga perlakuan bagi mendapatkan maksud atau niat pengucap tersebut terlaksana dan dapat dikenal pasti. Dalam teori LB ini, terdapat lima kategori yang digariskan oleh Searle (1969), iaitu asertif, direktif, komisif, ekspresif dan deklaratif.

\section{DAPATAN DAN PERBINCANGAN}

Daripada keselurahan filem yang dikaji, didapati terdapat konflik yang melatari plot cerita yang disampaikan. Konflik yang terdapat dalam filem merangkumi konflik perkelahian, kekecewaan dan 
ketidakpuasan hati atau dendam. Pengungkapan sesuatu ujaran dalam plot konflik dilihat dapat menentukan keperibadian seseorang melalui bahasa yang digunakan terutamanya bahasa kiasan (Siti Zuhaidah Zakeria dan Nik Rafidah Nik Muhamad Affendi, 2017). Pengungkapan ujaran bersifat kiasan dilihat dapat memancarkan akal budi bangsa Melayu. Berdasarkan dapatan yang diperoleh, jumlah keseluruhan konflik dalam filem yang dikaji adalah sebanyak 284 ujaran. Sebanyak 121 ungkapan yang digunakan dalam konflik perkelahian, 78 konflik ketidakpuasan hati dan 85 konflik kekecewaan. Jadual di bawah merupakan dapatan yang diperoleh yang memaparkan konflik dalam filem Nordin Ahmad.

Jadual 1. Jumlah Keseluruhan Konflik dalam Filem

\begin{tabular}{|c|c|c|c|c|c|}
\hline Filem/konflik & FSM & FHJ & FSP & FLK & Jumlah \\
\hline Perkelahian & 39 & 26 & 16 & 40 & $\mathbf{1 2 1}$ \\
\hline $\begin{array}{c}\text { Ketidakpuasan } \\
\text { Hati }\end{array}$ & 19 & 27 & 8 & 24 & $\mathbf{7 8}$ \\
\hline Kekecewaan & 21 & 21 & 13 & 30 & $\mathbf{8 5}$ \\
\hline Jumlah & $\mathbf{7 9}$ & $\mathbf{7 4}$ & $\mathbf{3 7}$ & $\mathbf{9 4}$ & $\mathbf{2 8 4}$ \\
\hline
\end{tabular}

\section{Konflik Perkelahian}

Daripada 284 ujaran keseluruhan, konflik perkelahian mencatatkan jumlah yang tinggi, iaitu sebanyak 121 dalam keempat-empat buah filem. Dalam konflik perkelahian, aspek bahasa dilihat sebagai satu bentuk pemikiran dalam mengungkapkan rasa marah, geram dan sebagainya. Persoalan pemikiran ini terpancar melalui bahasa yang digunakan terutamanya bahasa kiasan. Bahasa dalam mengungkapkan perkelahian dalam sesuatu konflik ini merangkumi aspek peribahasa atau bukan peribahasa. Antara bahasa kiasan dalam konflik perkelahian yang terdapat dalam filem adalah seperti yang berikut:

Jadual 2: Perkelahian dalam FSM

\begin{tabular}{|c|c|c|c|}
\hline Data & & & Ujaran \\
\hline \multirow[t]{3}{*}{ D1 } & $\mathbf{U 1}$ & Tambak & $\begin{array}{l}\text { Aku bukan ganggu kau Seri. Tapi, salahkah aku memuji suara kau yang } \\
\text { merdu itu. }\end{array}$ \\
\hline & $\mathbf{U} 2$ & Seri & $\begin{array}{l}\text { Jangan hidung tak mancung pipi tersorong-soronglah. Orang tak } \\
\text { cakap dengan dia nak cakap dengan orang. Muka tak malu }\end{array}$ \\
\hline & $\mathbf{U 3}$ & Tambak & Apa kau kata. Diam, diamlah. \\
\hline \multirow[t]{5}{*}{ D2 } & U4 & Damak & Aku sedar diri, Awang. Mengapa kau buat aku begitu? \\
\hline & U5 & Awang & $\begin{array}{l}\text { Kerana kau nak menunjuk kekuatan di hadapan Seri. Kau nak memikat } \\
\text { hati dia, ya. Kau mengalahkan Tambak. Kau benam-benamkan dia } \\
\text { dalam air. Sebab itu aku buat begini. }\end{array}$ \\
\hline & U6 & Damak & $\begin{array}{l}\text { Eh, Awang. Aku bukan macam kaulah. Kalau kau, ya, pantang } \\
\text { nampak perempuan dahi licin sikit. }\end{array}$ \\
\hline & U7 & Awang & $\begin{array}{l}\text { Oh, kau nak besar kepala, ya. Tambak bukan lawan kau. Kalau kau } \\
\text { betul anak lelaki, haa ni dia lawan kau. }\end{array}$ \\
\hline & $\mathbf{U 8}$ & Damak & Kalau kau sudi menjual aku sedia membeli, Awang. \\
\hline \multirow[t]{2}{*}{ D3 } & $\begin{array}{c}\text { U9 } \\
\text { U10 }\end{array}$ & $\begin{array}{l}\text { Penghulu } \\
\text { Malau }\end{array}$ & $\begin{array}{l}\text { Dah terang Malau, nampaknya si Damak nak mengotorkan nama kau. } \\
\text { Kau nak mengotorkan bumi Mersing, ya. Dagang merempat tak sedar } \\
\text { diri. }\end{array}$ \\
\hline & U11 & Damak & $\begin{array}{l}\text { Ya, saya tahu saya dagang merempat Pak Malau. Saya tak berniat nak } \\
\text { mengotorkan bumi Mersing, apa pun yang saya lakukan semata-mata } \\
\text { untuk menolong, Pak Malau. }\end{array}$ \\
\hline
\end{tabular}

Berdasarkan jadual 2 di atas, data yang dipaparkan mengandungi bahasa kiasan seperti dalam D1, 'Jangan hidung tak mancung pipi tersorong-soronglah', D2 'pantang nampak perempuan dahi licin sikit', 'Kalau 
kau sudi menjual aku sedia membeli' dan D3 'Damak nak mengotorkan nama kau'. Penggunaan bahasa kiasan yang mencerminkan perkelahian dapat dilihat melalui makna leksikal bahasa kiasan tersebut.

Jadual 3: Perkelahian dalam FHJ

\begin{tabular}{|c|c|c|c|}
\hline \multicolumn{3}{|l|}{ Data } & Ujaran \\
\hline D4 & U12 & Kasturi & $\begin{array}{l}\text { Bangkai gajah takkan dapat dilumur dengan pelapah pisang, bang } \\
\text { Jebat. }\end{array}$ \\
\hline & U13 & Jebat & $\begin{array}{l}\text { Oh, pasal Dang Baru, ya. Itu aku punya pasal. Cuka sama cuka, ulang } \\
\text { kali tidak dibeli, suka sama suka, orang lain yang membeli. }\end{array}$ \\
\hline & U14 & Kasturi & Perbuatan kau ini sungguh memalukan, Jebat. \\
\hline & U15 & Jebat & $\begin{array}{l}\text { Hei, tanah tinggi jangan dipertinggikan, tanah lembah jangan } \\
\text { diperdalami. Ha, ini Jebat apa yang boleh aku buat, apa yang aku buat } \\
\text { aku mengaku. Kalau suka tengok, kalau tak suka jalan. }\end{array}$ \\
\hline \multirow[t]{3}{*}{ D5 } & U16 & Jebat & $\begin{array}{l}\text { Tidak semudah itu saudara-saudara. Tetapi, walau bagaimanapun } \\
\text { jiwaku ini masih tetap berdiri untuk membela yang berhak dan berjuang } \\
\text { mengatasi kezaliman. }\end{array}$ \\
\hline & U17 & Lekiu & $\begin{array}{l}\text { Jebat, jangan kau cuba makan santan berlada, nanti kau } \\
\text { kepedasan. }\end{array}$ \\
\hline & U18 & Jebat & $\begin{array}{l}\text { Oh, aku yang bermain-main, kau orang yang bersungguh-sungguh } \\
\text { nampaknya. }\end{array}$ \\
\hline \multirow[t]{4}{*}{ D6 } & U19 & Tuah & $\begin{array}{l}\text { Jebat telah menderhaka, Jebat telah menjadi musuh Sultan. Jebat telah } \\
\text { menderhaka }\end{array}$ \\
\hline & U20 & Isteri & $\begin{array}{l}\text { Menderhaka untuk membelamu, bang. Menderhaka untuk membelamu } \\
\text { bang. Ya, abang hendak mengambil hati raja dan } \\
\text { mempersembahkan nyawa saudaramu sendiri. }\end{array}$ \\
\hline & U21 & Tuah & $\begin{array}{l}\text { Perkataan kau ini tajam, tajam seperti sembilu menghiris hati. } \\
\text { Kaulah seorang isteri yang melebihkan orang lain daripada suaminya } \\
\text { sendiri. }\end{array}$ \\
\hline & U22 & Isteri & Abang salah faham. \\
\hline
\end{tabular}

Seperti yang dipaparkan dalam jadual 3, bahasa kiasan yang dipersembahkan mempunyai makna yang kompleks dan memerlukan penaakulan dan kognitif yang tinggi untuk memperoleh makna sebenar ujaran tersebut. Ujaran yang mempunyai kadar kompleks yang tinggi adalah seperti D4 U13 'Cuka sama cuka, ulang kali tidak dibeli, suka sama suka, orang lain yang membeli', D4 U15 'tanah tinggi jangan dipertinggikan, tanah lembah jangan diperdalami' dan D6 U21 'Perkataan kau ini tajam, tajam seperti sembilu menghiris hati. Oleh yang demikian, untuk memperoleh makna sebenar bahasa kiasan tersebut, pengguna bahasa perlu melihat kepada konteks yang terbina, maklumat tambahan dan kesan konteks yang melatari perbualan tersebut.

Jadual 4: Perkelahian dalam FLK

\begin{tabular}{cccl}
\hline $\begin{array}{c}\text { Data } \\
\text { D7 }\end{array}$ & U23 & Ali & $\begin{array}{l}\text { Cik Telani, Cik Telani, Cik Telani bertuah betul mendapat kurnia } \\
\text { kalung emas (memegang kalung emas di leher Telani) }\end{array}$ \\
& U24 & Telani & $\begin{array}{l}\text { Datuk! kalau hendak berumah biarlah dindingnya papan, kalau } \\
\text { hendak dihormat biarlah bersopan. }\end{array}$ \\
Jangan begitu kasar, Telani. Jangan marah. \\
D8 & Un26 & Teratai & $\begin{array}{l}\text { Abang, kalau diharap pagar, pagar memakan padi. } \\
\text { Apa kau buat ke mari? }\end{array}$ \\
\hline
\end{tabular}




\begin{tabular}{lccl}
\hline U28 & Teratai & $\begin{array}{l}\text { Abang buat apa di sini? } \\
\text { Telani } \\
\text { Ingat, kalau Abang Yahya balik nanti, akan kau tahulah langit tinggi } \\
\text { rendah } \\
\text { Aku tak gentar itu semua. Sebelum Yahya pulang, akan kuhabiskan } \\
\text { kau terlebih dahulu. }\end{array}$ \\
$\mathbf{U 3 3}$ & Ali & Yahya & $\begin{array}{l}\text { Ali, kau lupa barangkali aku kenalkan akulah suami Telani yang kau } \\
\text { aniaya dulu. } \\
\text { Eh, Yahya, jangan pulak kau menyalahkan aku, Telani menjadi korban } \\
\text { adalah titah Sultan. } \\
\text { Kau yang berhutang mengapa Sultan pulak yang kau cagar } \\
\text { membayarnya? Aku datang menuntut hutang. Cabut kerismu } \\
\text { supaya dapat kita membuat kira. }\end{array}$ \\
\hline
\end{tabular}

Penggunaan bahasa kiasan tidak terhad kepada leksikal, ayat kompleks atau ayat penyata, namun penggunaan bahasa kiasan dalam berbentuk pantun berangkap juga memperlihatkan keindahan pemikiran masyarakat Melayu seperti dalam D7 U34 'kalau hendak berumah biarlah dindingnya papan, kalau hendak dihormat biarlah bersopan'. Perkara ini menunjukkan bahawa pemikiran masyarakat Melayu adalah berdinamik, iaitu mempunyai pelbagai cara untuk mengungkapkan sesuatu perasaan, emosi agar makna yang hendak disampaikan tidak menyinggung pendengar secara langsung.

Jadual 5: Perkelahian dalam FSP

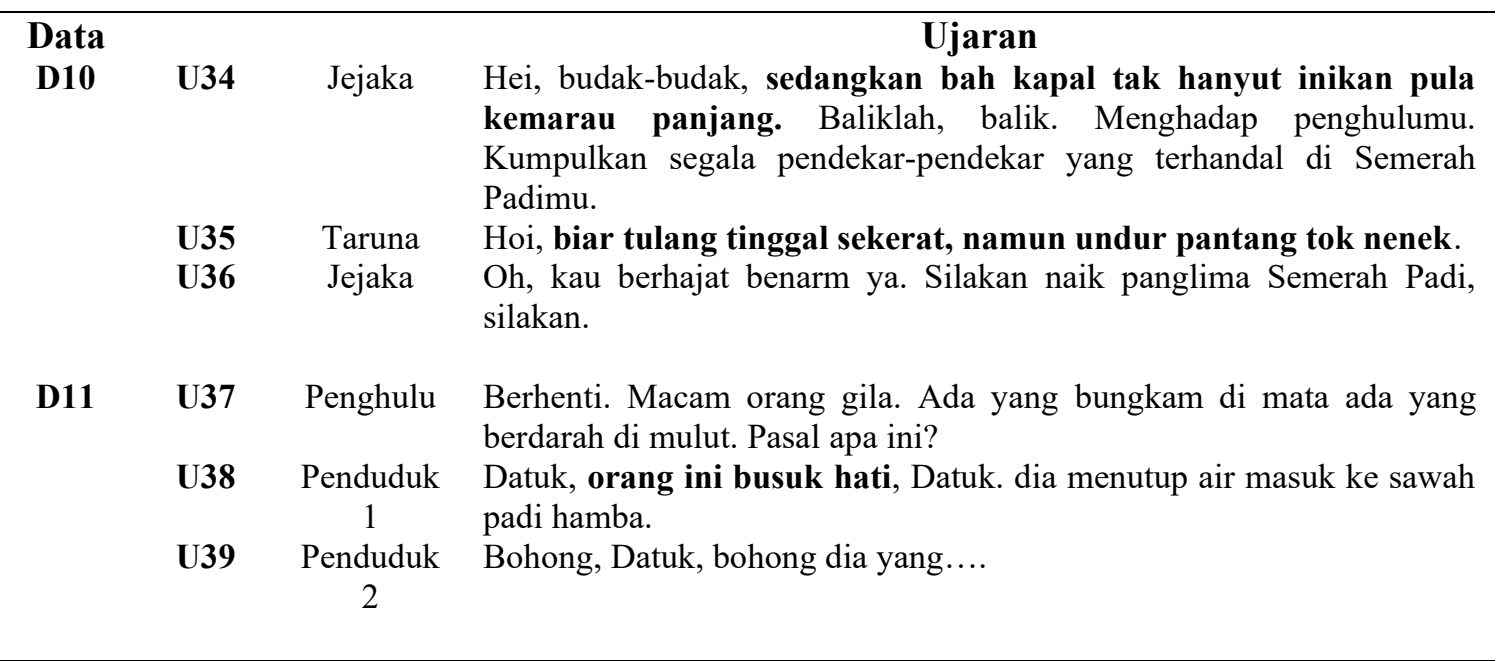

Berdasarkan jadual 2 hingga 5, data yang dipaparkan mengandungi ujaran bahasa kiasan dalam mengungkapkan sesuatu perkelahian. Bahasa kiasan yang dikesan adalah melalui lontaran dialog yang diujarkan oleh watak yang mempunyai makna bukan literal. Makna bahasa kiasan ini hanya dapat dikenal pasti makna sebenarnya apabila melihat kepada konteks dan kesan konteks yang relevans dengan ujaran yang dibekalkan dalam merungkai makna sebenarnya. Penganalisisan data yang dipaparkan adalah berdasarkan teori LB dan TR. Sebagai contoh, D2 FSM U6 dalam jadual 1 penutur mengungkapkan rasa marahnya terhadap pendengar dengan mengujarkan 'Eh, Awang. Aku bukan macam kaulah. Kalau kau, ya, pantang nampak perempuan dahi licin sikit'. Ujaran penutur tersebut difahami dan pendengar membalas ujaran tersebut melalui ujaran U7, 'Oh, kau nak besar kepala, ya. Tambak bukan lawan kau. Kalau kau betul anak lelaki, haa ni dia lawan kau'. Penutur rasa tercabar oleh ujaran yang didengari lalu membalas dengan mengujarkan U8, 'Kalau kau sudi menjual aku sedia membeli, Awang'. Berdasarkan pemaparan dan pemilihan data ini, penutur pada awalnya menyatakan rasa marahnya melalui U6 lakuan ekspresif emosi marah. Ujaran lakuan ekspresif ini kemudiannya difahami dan pendengar bertindak balas 
melalui ujaran U7 lakuan asertif. Ujaran penutur pada D2 U6, iaitu melalui lakuan ekspresif, penutur menyatakan rasa marahnya yang menunjukkan sikap psikologi dan mood penutur. Ujaran balas daripada pendengar dalam U7 merupakan lakuan asertif yang menunjukkan kepada kebenaran proposisi yang dilahirkan mempunyai nilai benar. Ujaran U8 yang diujarakan oleh penutur menunjukkan konflik yang timbul, iaitu melalui ujaran komisif yang bersifat pelawaan yang mengehendaki pendengar melakukan sesuatu seperti yang dikehendaki oleh penutur.

Ujaran Damak (U4, U6 \& U8) dan ujaran Awang (U5 \& U7) didapati kedua-dua penutur dan pendengar mudah memahami mesej yang disampaikan lalu berlangsungnya komunikasi. Hajat komunikatif antara kedua-dua komunikator ini mudah diproses berdasarkan konteks dan kesan konteks yang melatari perbualan tersebut. Pemahaman dan penginterpretasian sesuatu ujaran berbentuk kiasan memerlukan usaha yang maksimum dalam usaha untuk memahami makna sebenar ujaran tersebut. Dalam memproses ujaran bahasa kiasan seperti D2, pendengar selalunya memberikan perhatian terhadap perkara yang relevan dengan dirinya. Penginterpretasian makna ujaran Damak dalam D2 amat bergantung pada konteks perbualan. Konteks yang melatari perbualan tersebut adalah perkelahian antara Damak dengan Awang. Konteks dalam TR ialah pembinaan kognitif secara eksplisit. Konteks ialah seberkas andaian yang dibina secara psikologi oleh pendengar (Sperber \& Wilson, 1986). Konteks tidak terhad pada maklumat yang paling dekat, namun merangkumi masa depan, hipotesis saintifik, kepercayaan agama, andaian tentang budaya dan kepercayaan penutur. Konteks yang dibina dalam perbualan D2 di atas memperlihatkan konflik yang berlaku antara komunikator yang melibatkan penggunaan bahasa kiasan. Menurut Sperber \& Wilson (1986) fakta nyata dimanifestasi kepada individu adalah pada waktu tertentu jika dan hanya jika dia mampu pada masa tersebut mewakilinya secara mental dan menerima perwakilannya itu sebagai benar atau mungkin benar.

Ujaran kiasan Damak dalam D2 U6 dapat difahami oleh Awang dan begitu juga sebaliknya kerana Damak sebagai penutur telah membekalkan maklumat konteks yang relevan untuk ditafsir oleh Awang sebagai pendengar. Dengan berbekalkan konteks yang relevan, Damak dan Awang dapat memahami kiasan yang diujarkan kerana maklumat konteks yang disampaikan terbina dalam perbualan mereka menyentuh pengalaman yang sudah tercatat dalam ensiklopedia mereka. Perkelahian mereka yang menggunakan bahasa kiasan dilihat dapat difahami, walaupun menggunakan bahasa yang tersirat. Ujaran Damak dalam U6 dan U8 bersifat kiasan seperti 'perempuan dahi licin' dan 'kalau kau sudi menjual aku sudi membeli' dan ujaran Awang dalam U7, iaitu 'kau nak besar kepala, ya'. Ujaran ini dapat difahami dengan baik kerana Damak selaku penutur memberikan maklumat konteks yang maksimum kepada Awang untuk diproses dan diinterpretasi makna sebenar ujaran Damak. Awang selaku pendengar pula memproses maklumat yang diterima dengan kadar yang minimum disebabkan oleh pemerolehan maklumat yang relevan dan berbaloi untuk diproses. Awang dapat memahami perkelahian yang terjadi berdasarkan ujaran dan maklumat yang diperoleh berkisarkan peristiwa yang pernah dilalui oleh mereka bersama.

Konteks dan maklumat konteks yang dibekalkan dapat membantu komunikator menginterpretasi ujaran seperti D2 di atas. Bahasa kiasan yang digunakan seperti jadual di atas dapat dirungkai dan difahami hajat komunikatif penutur berdasarkan konteks dan maklumat konteks yang maksimum. Hal ini kerana konteks akan membekalkan maklumat konteks kepada pendengar untuk diproses dan diinterpretasi makna ujaran tersebut. Sekiranya pendengar gagal untuk memahami konteks perbualan, maka maklumat konteks yang diperoleh gagal untuk difahami dan berlakunya salah faham. Bagi mengelakkan salah tafsiran ujaran terutamanya bahasa kiasan, komunikator perlulah memahami konteks perbualan dan berusaha untuk mendapatkan maklumat konteks semaksimum mungkin. Bahasa kiasan yang terdapat dalam D2 di atas mudah diproses berdasarkan konteks dan kesan konteks yang maksimum, walaupun usaha memproses maklumat ujaran ini melibatkan kos yang tinggi. 


\section{KONFLIK KETIDAKPUASAN HATI}

Dalam menyatakan ketidakpuasan hati, penutur diberi perhatian sama ada untuk menyatakan rasa tidak puas hati tersebut secara langsung atau tidak langsung. Berdasarkan dapatan penyelidikan ini, perkara yang menarik diperoleh, iaitu penutur menggunakan bahasa kiasan dalam mengungkapkan rasa tidak puas hatinya kepada pendengar dan mesej yang disampaikan dapat diinterpretasi dengan tepat. Antara dapatan yang diperoleh adalah seperti jadual di bawah;

Jadual 6: Bahasa Kiasan Ketidakpuasan Hati dalam FSM

\begin{tabular}{|c|c|c|c|}
\hline \multirow{2}{*}{$\begin{array}{c}\text { Data } \\
\text { D12 }\end{array}$} & \multirow[b]{2}{*}{ U40 } & & Ujaran \\
\hline & & Siantan & $\begin{array}{l}\text { Nampaknya Seri nak potong jalan aku. Padahal aku yang lebih dulu } \\
\text { kenal dengan Damak }\end{array}$ \\
\hline & U41 & Siti & Sudahlah, apa yang hendak digaduhkan. \\
\hline & $\mathbf{U} 42$ & Dayang & Haah Siantan, apa yang kau nak gaduh-gaduhkan. \\
\hline & U43 & Siantan & $\begin{array}{l}\text { Kau tengoklah siti. Kalau aku tak dapat kahwin dengan Damak, taka } \\
\text { da seorang pun anak dara dalam Mersing ini yang dapat berkahwin } \\
\text { dengannya. Kau tahu tak. }\end{array}$ \\
\hline \multirow[t]{5}{*}{ D13 } & U44 & Banang & Barang kali Awang Sulung yang melakukan perbuatan itu. \\
\hline & U45 & Malau & $\begin{array}{l}\text { Jangan kau cuba menegakkan benang basah. Apa kau tidak suka } \\
\text { berbesankan Penghulu? }\end{array}$ \\
\hline & U46 & Banang & Ada ke tak suka, bang. Tapi biarlah kena dengan jalannya. \\
\hline & U47 & Malau & Ha, ini kena dengan jalannya, sebab itu aku bersetuju. \\
\hline & U48 & Seri & $\begin{array}{l}\text { Seri tak setuju. seri tak setuju. seri rela mati daripada menjadi isteri } \\
\text { manusia yang kejam. }\end{array}$ \\
\hline \multirow[t]{2}{*}{ D14 } & U49 & Seri & Seri tak suka berkahwin dengan Awang, ayah. \\
\hline & U50 & Malau & $\begin{array}{l}\text { Jadi kau nak memilih jodoh sendiri, ya. Aku tidak akan terpengaruh } \\
\text { oleh kemahuan kau, Seri. Di mana duduknya kekuasaan aku } \\
\text { sebagai seorang ayah. Kau keluar, kau pergi, keluar. Keluar kau. }\end{array}$ \\
\hline
\end{tabular}

Ujaran bahasa kiasan ketidakpuasan hati berlaku disebabkan oleh beberapa faktor antaranya ketidakpuasan hati berdasarkan perilaku, keputusan, ujaran dan tindakan seseorang. Antara bahasa kiasan ketidakpuasan hati yang diperoleh dalam jadual 6 adalah seperti 'Seri nak potong jalan aku', 'Jangan kau cuba menegakkan benang basah' dan 'Di mana duduknya kekuasaan aku sebagai seorang ayah'.

Jadual 7: Bahasa Kiasan Ketidakpuasan Hati dalam FHJ

\begin{tabular}{|c|c|c|c|}
\hline Data & & & Ujaran \\
\hline \multirow[t]{3}{*}{ D15 } & U51 & Bendahara & $\begin{array}{l}\text { Ampun Tuanku, sembah patik harap diampun. Patik pohonkan } \\
\text { janganlah ke bawah duli pacal Hang Tuah di dalam murka, } \\
\text { Tuanku. Ampun Tuanku. }\end{array}$ \\
\hline & U52 & Sultan & $\begin{array}{l}\text { Tidak. Tidak Bendahara. Apa yang beta telah kata tidak akan } \\
\text { berginjak dari maksudnya. }\end{array}$ \\
\hline & U53 & Bendahara & $\begin{array}{l}\text { Ampun Tuanku. Mudah ke bawah duli sangat benar, tetap } \\
\text { pada pendapat patik hukuman dari seorang raja itu, Tuanku } \\
\text { hendaklah dengan neracanya yang bijak, Tuanku. Jika tidak, } \\
\text { tak ubah seperti kebun tidak berpagar, Tuanku. Ampun } \\
\text { Tuanku. }\end{array}$ \\
\hline \multirow[t]{2}{*}{ D16 } & U54 & Kasturi & $\begin{array}{l}\text { Begitu jugak dunia ini, Jebat. Kalau tiada khianat dan dengki } \\
\text { tidak dinamakan dunia. }\end{array}$ \\
\hline & U55 & Jebat & Aku tidak berpuas hati sebelum dapat menghirukkan darah \\
\hline
\end{tabular}




\begin{tabular}{cccc}
\hline U56 & Lekiu & $\begin{array}{l}\text { orang yang membuat angkara. } \\
\text { Apa yang katakan fitnah, dengki dan membuat angkara? } \\
\text { Siapakah orangnya? Adakah kau maksudkan Sultan atau orang } \\
\text { besarnya } \\
\text { Ya. Kau orang tahu nanti. Perahu sudah di air hanya } \\
\text { menunggu dayung untuk kukayuh. } \\
\text { D17 }\end{array}$ Jebat tidak mahu dengar. Aku tidak mahu dengar. Aku \\
& U58 & Isteri Tuah & $\begin{array}{l}\text { Aku...Jebat, berilah aku tahu Jebat, terangkan kepada aku. } \\
\text { Apa mulanya, Jebat? } \\
\text { Akan aku tunaikan. Mulanya angkara Tun Teja. Setitik air } \\
\text { mata yang mengalir akan kusukat dengan darah kepada } \\
\text { mereka yang bertanggungawab. Mereka berniaga dengan } \\
\text { darah, juga darahlah aku bayar hutangnya. }\end{array}$ \\
\hline
\end{tabular}

Jadual 7 di atas memaparkan bahasa kiasan yang menjelaskan rasa tidak puas hati terhadap perbuatan seseorang. Bahasa kiasan yang mencerminkan ketidakpuasan hati terhadap perbuatan seseorang dalam jadual 7 adalah seperti 'tak ubah seperti kebun tidak berpagar', 'Perahu sudah di air hanya menunggu dayung untuk kukayuh' dan 'Setitik air mata yang mengalir akan kusukat dengan darah kepada mereka yang bertanggungjawab. Mereka berniaga dengan darah, juga darahlah aku bayar hutangnya'. Kesan daripada perbuatan seseorang menjadi penyebab penutur atau pendengar mengujarkan sesuatu ujaran yang berunsurkan ketidakpuasan hati seperti yang terdapat dalam jadual 7.

Jadual 8: Bahasa Kiasan Ketidakpuasan Hati dalam FLK

\begin{tabular}{|c|c|c|c|}
\hline \multicolumn{3}{|l|}{ Data } & Ujaran \\
\hline D18 & $\mathbf{U 6 0}$ & Teratai & $\begin{array}{l}\text { Abang, kalau abang hendak bercerminkan bangkai seumur hidup, } \\
\text { bunuhlah kami berdua, tak malukah abang berkelakuan begini. } \\
\text { Sebelum orang lain tahu, lebih baik abang keluar. }\end{array}$ \\
\hline & U61 & Ali & $\begin{array}{l}\text { Ya, tapi ingat, aku berundur bukan bererti kalah, aku berundur } \\
\text { untuk membuka langkah. Malu tebusnya darah. }\end{array}$ \\
\hline \multirow[t]{3}{*}{ D19 } & U62 & Ali & $\begin{array}{l}\text { Tok Pawang sudah berapa kali saya meminta pertolongan untuk } \\
\text { mendapatkan Telani, tapi pembohong, ilmu tak faham semata-mata } \\
\text { karut. Akhirnya saya jugak yang berputih mata. }\end{array}$ \\
\hline & U63 & Pawang & Hamba telah ikhtiar sedaya upaya, tapi... \\
\hline & U64 & Ali & $\begin{array}{l}\text { Kalau Tok Pawang tak turut kemahuan saya, saya akan simbah } \\
\text { Lanchang Kuning dengan darah Tok Pawang. }\end{array}$ \\
\hline \multirow[t]{3}{*}{ D20 } & U65 & Yahya & Kalau berpesan diturut, kalau berhutang dituntut. \\
\hline & U66 & Mak Inang & Yahya, fikir dulu nak kerana berfikir itu pelita hati. \\
\hline & U67 & Yahya & Tolong, jangan diganggu tujuan saya. \\
\hline
\end{tabular}

Berdasarkan jadual 6 hingga 8 di atas, data yang dipaparkan merupakan data bahasa kiasan yang terdapat dalam filem Melayu terpilih. Ujaran yang diujarkan oleh penutur dilihat dapat difahami oleh pendengar walaupun menggunakan bahasa kiasan. Ujaran yang diujarkan juga mempunyai hajat, iaitu untuk menyatakan ketidakpuasan hati terhadap sesuatu perkara atau seseorang. Mengungkapkan sesuatu perkara dengan menggunakan bahasa kiasan dilihat dapat menonjolkan keperibadian seseorang di samping mencerminkan kebudayaan Melayu yang amat mementingkan kesantunan dalam berkomunikasi. Sebagai contoh, D18 merupakan perbualan yang berlangsung dalam konteks ketidakpuasan hati penutur yang mendakwa pendengar mengganggu seseorang. Ujaran ini dapat dilihat melalui U60, iaitu 'Abang, kalau abang hendak bercerminkan bangkai seumur hidup, bunuhlah kami berdua, tak malukah abang berkelakuan begini. Sebelum orang lain tahu, lebih baik abang keluar'. Ujaran U60 oleh Teratai ini merupakan ujaran LB direktif yang menggambarkan usaha penutur untuk membuatkan pendengar 
melakukan sesuatu yang dihajatkan. Ujaran direktif ini difahami dan diperlakukan seperti yang dihajati oleh hajat komunikatif penutur, melalui U61, iaitu 'Ya, tapi ingat, aku berundur bukan bererti kalah, aku berundur untuk membuka langkah. Malu tebusnya darah'. Ujaran dalam U61 ini merupakan satu bentuk LB komisif ugutan yang diujarkan oleh Ali untuk mengancam Teratai yang mengganggu tujuannya. Ujaran LB komisif ugutan Ali ini merupakan perlakuan LB yang memperlihatkan penutur kepada sesuatu tindakan pada masa akan datang. Jelasnya di sini bahawa ujaran bahasa kiasan dalam menyampaikan rasa tidak puas hati dapat difahami oleh komunikator berdasarkan faktor LB, konteks dan kesan konteks perbualan.

Penyataan Teratai dalam U60 telah membekalkan maklumat konteks untuk memudahkan Ali memproses hajat komunikatifnya. Konteks yang disampaikan dapat difahami oleh Ali walaupun ujaran Teratai mengandungi bahasa kiasan, seperti dalam U60. Konteks yang melatari perbualan dalam D18 merupakan peristiwa yang berlangsung bersama-sama dan kedua-dua penutur dan pendengar mengalami pengalaman yang sama. Justeru itu, Carston (2010) mengatakan bahawa sesuatu konteks perbualan itu menjadi relevan sekiranya penutur dan pendengar mengalami peristiwa, pengalaman, situasi dan latar bersama-sama. Perkara ini juga melibatkan pengetahuan ilmu mengenai sesuatu perkara, peristiwa, fenomena alam, dan kebudayaan sesuatu bangsa.

Berdasarkan konteks yang telah dibina dalam D18, maklumat konteks yang dibekalkan oleh penutur juga maksimum dan membolehkan pendengar menginterpretasi ujaran dengan kadar yang minimum walaupun ujaran tersebut merupakan ujaran bahasa kiasan. Maklumat konteks yang diberikan oleh Teratai, iaitu 'kalau abang hendak bercerminkan bangkai seumur hidup, bunuhlah kami berdua, tak malukah abang berkelakuan begini. Sebelum orang lain tahu, lebih baik abang keluar' dapat difahami dan berbaloi untuk diproses kerana maklumat yang diberikan ini merupakan maklumat yang relevan kepada pendengar. Perkara ini membuktikan bahawa kesan kognitif atau kesan konteks telah berperanan dalam membekalkan konteks dan kesan kognitif sehingga menjadikan kos proses mencapai tahap yang minimum (Aminnudin Saimon \& Zaitul Azma Zainon Hamzah, 2016).

Dalam menginterpretasi makna hajat komunikatif perlulah berdasarkan konteks dan kesan konteks yang maksimum. Kesan kognitif amat mempengaruhi seseorang untuk memahami makna yang hendak disampaikan keran kesan kognitif inilah yang membantu pendengar memproses makna. Maklumat diperoleh akan ditafsir dan diproses berdasarkan andaian-andaian yang diterima termasuklah maklumat mengenai penutur, peristiwa bersama, dan pengalaman bersama. Bahasa kiasan yang digunakan dalam menyatakan rasa tidak puas hati dilihat dapat difahami dan ditafsir dengan baik oleh komunikator disebabkan oleh maklumat yang maksimum dan pemahaman terhadap konteks perbualan. Pengungkapan bahasa kiasan dalam menyatakan ketidakpuasan hati mencerminkan budaya masyarakat Melayu yang amat mementingkan kehalusan budi, akal budi, falsafah dan kesantunan semasa berkomunikasi.

\section{KONFLIK KEKECEWAAN}

Mengungkapkan rasa kecewa sering kali melibatkan penggunaan bahasa emosional seperti sedih, hampa, dan berputus asa. Dalam dapatan kajian ini, pengungkapan rasa kecewa dilihat amat menarik untuk diikuti kerana masyarakat Melayu sering kali mengungkapkan rasa kecewanya menggunakan bahasa kiasan. Oleh itu, perhatikan jadual di bawah yang memaparkan ujaran kekecewaan dalam konteks konflik:

Jadual 9: Kekecewaan dalam FSM

\begin{tabular}{cccl}
\hline $\begin{array}{c}\text { Data } \\
\text { D21 }\end{array}$ & U68 & Seri & $\begin{array}{l}\text { Hantarlah Mak Bunga supaya lekas Awang bersanding dengan } \\
\text { bayangnya. }\end{array}$ \\
U69 & Mak Bunga & $\begin{array}{l}\text { Eh, kenapa cakap begitu, Seri. Sepatutnya orang nak kahwin } \\
\text { bersukalah, nak. } \\
\text { Kerana sukalah air mata saya tidak henti-henti keluar, Mak }\end{array}$ \\
\hline
\end{tabular}




\begin{tabular}{|c|c|c|c|}
\hline & & & Bunga. \\
\hline & U71 & Mak Bunga & $\begin{array}{l}\text { Tak baik kau bercakap begitu, nak. Bertuah kau dapat berkahwin } \\
\text { dengan anak Penghulu. }\end{array}$ \\
\hline & U72 & Seri & $\begin{array}{l}\text { Tak mana untungnya Mak Bunga memang nasib Seri sendiri yang } \\
\text { sial. }\end{array}$ \\
\hline D22 & U73 & Malau & $\begin{array}{l}\text { Jangan pulang Damak kerana orang-orang kampung di sini sangat } \\
\text { suka kepada kau supaya tinggal di Mersing. }\end{array}$ \\
\hline & U74 & Damak & $\begin{array}{l}\text { Saya telah merasai bagaimana pahitnya hidup di tempat orang. Hujan } \\
\text { emas di negeri orang, hujan batu di negeri saya, adalah lebih baik } \\
\text { di negeri saya, Pak Malau }\end{array}$ \\
\hline & U75 & Malau & $\begin{array}{l}\text { Perkara yang sudah janganlah diulang lagi, Damak, tetapi kuharap } \\
\text { terimalah tawaranku ini. }\end{array}$ \\
\hline & U76 & Damak & $\begin{array}{l}\text { Tidak. Kajang Pak Malau kajang berlipat, kajang saya } \\
\text { mengkuang layu, dagan Pak Malau dagang bertempat, dagang } \\
\text { saya musafir lalu. Saya pergi dulu. }\end{array}$ \\
\hline D23 & U77 & Malau & $\begin{array}{l}\text { Keras batu dapat dilekukkan oleh air, tetapi keras hati kau tak } \\
\text { dapat dilentur dengan lidah. Sampaikah hati kau, Damak. }\end{array}$ \\
\hline & U78 & Damak & $\begin{array}{l}\text { Pak Malau, apa ada kepada paya, dalam tidak sumur pun bukan, } \\
\text { apa ada pada saya berbangsa tidak masyhurpun bukan. }\end{array}$ \\
\hline
\end{tabular}

Konflik kekecewaan dalam filem dilihat sebagai satu dapatan yang menarik untuk dianalsis kerana konflik ini menceritakan emosi peserta komunikasi dalam sesuatu peristiwa. Kekecewaan berlaku disebabkan oleh perbuatan seseorang yang menguris atau menyakitkan hati. Ujaran bersifat kekecewaan ini lebih menjurus kepada ujaran yang mempunyai gaya emosional sedih. Oleh itu, ujaran kekecewaan yang diperoleh adalah seperti 'Kajang Pak Malau kajang berlipat, kajang saya mengkuang layu, dagan Pak Malau dagang bertempat, dagang saya musafir lalu' dan 'apa ada kepada paya, dalam tidak sumur pun bukan, apa ada pada saya berbangsa tidak masyhurpun bukan'.

Jadual 10: Kekecewaan dalam FHJ

\begin{tabular}{|c|c|c|c|}
\hline $\begin{array}{l}\text { Data } \\
\text { D24 }\end{array}$ & \multicolumn{3}{|r|}{ Ujaran } \\
\hline D24 & U79 & Bendahara & $\begin{array}{l}\text { Ampun Tuanku, sembah Temenggung Jebat bermaharaja lela dan } \\
\text { banyak tentera diraja telah tewas. Ampun Tuanku. }\end{array}$ \\
\hline & U80 & Permaisuri 1 & Ampun Tuanku, Tuanku suka mengikut rasakan akhirnya binasa \\
\hline & U81 & Permaisuri 2 & $\begin{array}{l}\text { Sesal dahulu pendapatan, sesal kemudian tidak berguna. } \\
\text { Kalaulah Tuah masih hidup, tidaklah kita jadi begini. }\end{array}$ \\
\hline & U82 & Sultan & $\begin{array}{l}\text { Ya, ya, Hang Tuah. Mengapa kau kubunuh Tuah. Jika dibandingkan } \\
\text { dengan si Jebat derhaka itu si Tuahlah hambaku yang setia. Tidak } \\
\text { yang menderhaka dan tidak melawan bila dihukum. Mengapa } \\
\text { memanda membunuh si Tuah? }\end{array}$ \\
\hline & U83 & Bendahara & Ampun Tuanku ke bawah dulu juga yang menitahkan begitu. \\
\hline D25 & U84 & Sultan & $\begin{array}{l}\text { Hang Tuah rupanya kau masih hidup Tuah. Jika dosanya seluas tujuh } \\
\text { lautan dan tingginya seperti Sembilan gunung sekalipun beta akan } \\
\text { ampunkan, memanda asal saja si Tuah dapat menghapuskan orang } \\
\text { yang menconteng arang ke muka beta. }\end{array}$ \\
\hline & & Bendahara & Ampun Tuanku, dunia penuh dengan teka-teki. \\
\hline
\end{tabular}

Jadual 10 di atas memaparkan ujaran kekecewaan yang terdapat dalam filem Melayu terpilih. Dalam mengungkapkan kekecewaan, masyarakat Melayu juga sering kali menggunakan peribahasa dalam menyampaikan emosi mereka. Peribahasa yang diperoleh dalam menyampaikan emosi kekecewaan 
adalah seperti 'Sesal dahulu pendapatan, sesal kemudian tidak berguna' dan 'orang yang menconteng arang ke muka beta'.

Jadual 11: Kekecewaan dalam FLK

\begin{tabular}{|c|c|c|c|}
\hline \multicolumn{3}{|l|}{ Data } & Ujaran \\
\hline D26 & U85 & Telani & $\begin{array}{l}\text { Apa hendak dikata, kerana kata telah putus. Biarlah saya berundur } \\
\text { membawa diri dengan segala kesan kenangan indah. Kerna kuharap } \\
\text { hidup menjejak pantai, rupanya karam di tengah lautan. }\end{array}$ \\
\hline & U86 & Yahya & $\begin{array}{l}\text { Telani, aku datang untuk menyusun jari meminta maaf. Maafkanlah } \\
\text { aku. Aku terlanjur kata, terlanjur bahasa. }\end{array}$ \\
\hline & U87 & Telani & $\begin{array}{l}\text { Terlanjur budi dikenang, terlanjur kata hati terkesan. Sudah, } \\
\text { lupakanlah peristiwa yang telah berlalu. }\end{array}$ \\
\hline & U88 & Yahya & $\begin{array}{l}\text { Telani, aku ke mari untuk memadam kesan. Kesan buruk yang kubuat } \\
\text { kerna tak usul periksa. }\end{array}$ \\
\hline & U89 & Telani & $\begin{array}{l}\text { Dalam dunia ini, banyak racun berupa penawar. Walaupun } \\
\text { penawar kuminum telah menjadi racun. Kasih yang kupuja telah } \\
\text { menyeksa jiwa, tapi kuingin mengekal kesan itu hingga ke mati. } \\
\text { Sebagai memetik kasihku yang suci dan tak berbelah bagi. Jangan } \\
\text { bimbang kan saya yang hanya penari dina. Biarkan saya pergi. }\end{array}$ \\
\hline \multirow[t]{4}{*}{ D27 } & U90 & Yahya & Teratai, apa maksudmu? \\
\hline & U91 & Teratai & $\begin{array}{l}\text { Abang Yahya, selama ini saya menari tidak berdendang, } \\
\text { berdayung tak bersampan, bercinta dengan bayangan. }\end{array}$ \\
\hline & U92 & Yahya & $\begin{array}{l}\text { Hai Teratai, aku tidak tahu kau ada menyimpan mutiara suci di } \\
\text { hatimu. Kau kupandang tak ubah adik kandungku. Kau marah aku? }\end{array}$ \\
\hline & U93 & Teratai & $\begin{array}{l}\text { Tidak, saya tidak marahkan abang. Saya hanya kesalkan diri sendiri. } \\
\text { Tapi lupakan itu semua. Maafkanlah saya kerana mengganggu } \\
\text { kegembiraan abang. }\end{array}$ \\
\hline
\end{tabular}

Jadual 11 di atas memaparkan ujaran kekecewaan bahasa kiasan makna mudah. Hal ini bermaksud ujaran bahasa kiasan dapat difahami maknanya dengan mudah. Dalam erti kata yang lain, makna yang hendak disampaikan mudah diproses dan mudah difahami. Hal ini disebabkan oleh penggunaan leksikal dalam bahasa kiasan yang mempunyai persamaan makna dan maklumat ensiklopedia. Antara bahasa kiasan yang diperoleh adalah seperti 'Kerna kuharap hidup menjejak pantai, rupanya karam di tengah lautan', 'Terlanjur budi dikenang, terlanjur kata hati terkesan', dan 'selama ini saya menari tidak berdendang, berdayung tak bersampan, bercinta dengan bayangan'

Jadual 12: Kekecewaan dalam FSP

\begin{tabular}{|c|c|c|c|}
\hline \multirow{5}{*}{$\begin{array}{c}\text { Data } \\
\text { D28 }\end{array}$} & \multicolumn{3}{|r|}{ Ujaran } \\
\hline & U94 & Dara & $\begin{array}{l}\text { Ya, bapak. Daralah yang menyebabkan semua ini. Ampunkanlah } \\
\text { Dara, bapak. Ampunkanlah Dara, bapak. Kerana cinta, keran cinta } \\
\text { Dara serahkan kehormatan, Dara berdosa, Dara berdosa, Dara } \\
\text { melakukan perbuatan keji. Menyesal, Dara menyesal, bapak. }\end{array}$ \\
\hline & U95 & Penghulu & $\begin{array}{l}\text { Walau seribu sesal kau sesalkan, namun noda tetap noda. Kusemai } \\
\text { padi lalang menjadi, sekandang kerbau mengikut kata anak } \\
\text { seorang mencolok mata. Dengan siapa? }\end{array}$ \\
\hline & U96 & Aduka & $\begin{array}{l}\text { Dengan saya. Pedang penghapus dosa sudah sedia. Saya rela mati } \\
\text { daripada menanggung malu. }\end{array}$ \\
\hline & U97 & Penghulu & $\begin{array}{l}\text { Aduka? Sungguh tergamak kau memutus jambatan penghubung } \\
\text { mesra. Seluruh keturunanku dan keturunanmu tercemar sudah, hanya } \\
\text { hukum agama sahaja yang dapat mengikis cemarku di dahi. }\end{array}$ \\
\hline
\end{tabular}


Berdasarkan jadual 9 hingga 12 yang dipaparkan, ujaran yang diujarkan oleh penutur mempunyai maklumat linguistik, iaitu bahasa kiasan. Penggunaan bahasa kiasan dalam mengungkapkan rasa kecewa dilihat satu dapatan yang menarik dalam kosa ilmu pragmatik. Hal ini demikian kerana ungkapan bahasa kiasan yang diujarakan dapat meminimumkan konflik yang berlaku di samping memperlihatkan ketinggian pemikiran seseorang. Sebagai contoh, U73 hingga U76 merupakan ujaran yang memaparkan kekecewaan Damak kerana diperlakukan dan dilayan dengan cara yang kurang sopan. Ujaran Pak Malau dalam U73, iaitu 'Jangan pulang Damak kerana orang-orang kampung di sini sangat suka kepada kau supaya tinggal di Mersing' merupakan satu bentuk LB komisif pemujukan. Hal ini dapat dilihat pada leksikal yang digunakan seperti ‘jangan pulang Damak' dan 'orang kampung di sini suka kepada kau' merupakan konteks yang mengehendaki pendengar melakukan sesuatu pada masa akan datang. Ujaran Damak dalam U74, iaitu 'Saya telah merasai bagaimana pahitnya hidup di tempat orang. Hujan emas di negeri orang, hujan batu di negeri saya, adalah lebih baik di negeri saya, Pak Malau' merupakan satu bentuk LB komisif penolakan. Dalam ujaran Damak ini, Damak telah mengujarkan satu bentuk peribahasa, iaitu 'hujan emas di negeri orang, hujan batu di negeri saya, adalah lebih baik di negeri saya' merupakan satu bentuk penolakan yang amat santun dan menjaga sensitiviti penutur. Peribahasa tersebut mempunyai makna tempat sendiri adalah lebih baik berbanding dengan tempat orang (Abdullah Hassan \& Ainon Mohd., 2011). Berdasarkan penolakan yang dibuat oleh Damak ini, pendengar, iaitu Pak Malau memahami ujaran peribahasa tersebut dan membalas melalui ujaran U75, iaitu 'Perkara yang sudah janganlah diulang lagi, Damak, tetapi kuharap terimalah tawaranku ini'. Ujaran Pak Malau ini merupakan satu bentuk LB komisif penawaran yang mengehendaki pendengar melakukan sesuatu seperti mana hajat komunikatifnya pada masa akan datang. Ujaran ini kemudiannya difahami oleh Damak yang membalas ujaran tersebut menggunakan bahasa kiasan, iaitu 'Tidak. Kajang Pak Malau kajang berlipat, kajang saya mengkuang layu, dagang Pak Malau dagang bertempat, dagang saya musafir lalu. Saya pergi dulu'. Berdasarkan D22, jelaslah difahami bahawa penutur menggunakan bahasa kiasan adalah disebabkan beberapa faktor dan bukan hanya untuk menjaga aib seseorang. Penggunaan bahasa kiasan dalam konflik dilihat mempunyai pelbagai strategi dan tujuan, antaranya menjaga aib, menolak sesuatu pelawaan, menyatakan kekecewaan dan menyampaikan niat.

Kebolehan pendengar mentafsir makna ujaran kiasan ini dipengaruhi oleh konteks dan kesan kognitif. Kekecewaan Damak dapat dilihat melalui bahasa kiasan yang diujarkan dan Pak Malau dapat memahaminya berdasarkan peristiwa-peristiwa lain yang berlaku sebelum ujaran atau peristiwa dalam D22 berlaku. Berdasarkan turutan peristiwa yang berlaku antara penutur dengan pendengar serta maklumat konteks yang dibekalkan adalah maksimum. Hal ini diperjelas oleh Sperber \& Wilson (1995) mengatakan bahawa maklumat tentang persekitaran yang paling dekat dan ujaran yang terdahulu yang paling hampir, hipotesis saintifik, kepercayaan agama, kenangan lampau, andaian am tentang budaya dan kepercayaan memainkan peranan yang penting dalam penginterpretasian makna ujaran termasuklah bahasa kiasan. Dalam menginterpretasi ujaran, hubungan antara penutur dengan pendengar akan memudahkan lagi penginterpretasian ujaran kerana hubungan yang rapat disebabkan maklumat yang ada tersimpan dalam ensiklopedia masing-masing. Dalam hal ini, penutur dan pendengar mempunyai maklumat yang maksimum yang diperoleh berdasarkan peristiwa-peristiwa yang dilalui oleh mereka bersama (Aminnudin Saimon \& Zaitul Azma Zainon Hamzah, 2016). Oleh yang demikian, bahasa kiasan yang terdapat dalam jadual di atas ini dapat difahami sebagai konflik oleh komunikator dengan berbekalkan konteks dan maklumat konteks yang maksimum bagi membantu pemprosesan makna sebenar bahasa kiasan.

Penginterpretasian menjadi mudah apabila penutur membekalkan maklumat konteks yang maksimum dan yang diperlukan oleh pendengar untuk diproses dan diinterpretasi. Semasa menyampaikan sesuatu hajat komunikatif, penutur seharusnya bertanggungjawab memastikan ujarannya mengandungi maklumat yang sama dengan perhatian pendengar. Hal ini sejajar dengan prinsip relevan, iaitu pendengar memberi perhatian kepada maklumat yang relevan kepada dirinya. Oleh hal yang demikian, konteks yang dibina akan membantu pendengar mengembangkan, menyingkir atau memperkuat maklumat yang diperoleh. Konteks dan kesan konteks yang diperoleh adalah maksimum akan memudahkan pendengar 
untuk menginterpretasi maklumat tersebut sebagai relevan kepada dirinya atau tidak. Dengan kata yang mudah, kesan konteks yang maksimum dan relevan akan membantu pendengar menginterpretasi maklumat menjadi relevan pada kadar yang minimum.

\section{IMPLIKASI DAPATAN KAJIAN}

Bahasa kiasan menyingkap secara tersurat dan tersirat akan pemikiran Melayu yang kreatif dalam berfalsafah untuk mengungkapkan pelbagai perkara, antaranya mencetuskan konflik kekecewaan, ketidakpuasan hati dan perkelahian. Dalam hal ini, bahasa merupakan entiti mental yang wujud dalam pemikiran setiap individu. Melalui penggunaan bahasa kiasan dalam menyampaikan dan mengungkapkan sesuatu konflik dilihat mempunyai nilai estetika yang tersendiri. Berdasarkan penggunaan bahasa kiasan dalam konflik, sesuatu konsep yang terbina dalam mengungkapkan sesuatu konflik terpancar dalam pemikiran dan diterjemahkan melalui ujaran, seterusnya diinterpretasi makna hajat komunikatif tersebut. Penggunaan unsur-unsur alam yang terdapat dalam data yang dipaparkan, antaranya bahasa kiasan 'Hei, tanah tinggi jangan dipertinggikan, tanah lembah jangan diperdalami', 'Hei, budak-budak, sedangkan bah kapal tak hanyut inikan pula kemarau panjang', 'Kau orang tahu nanti. Perahu sudah di air hanya menunggu dayung untuk kukayuh dan 'selama ini saya menari tidak berdendang, berdayung tak bersampan, bercinta dengan bayangan'.

Penggunaan bahasa kiasan dalam ujaran merupakan satu bentuk konsep dan pemikiran bangsa Melayu yang merujuk kepada objek dan perlakuan secara benar dan bersifat objektif. Penggunaan bahasa kiasan ini juga mencerminkan kebijaksanaan, ketinggian pemikiran, falsafah dan akal budi yang terdapat dalam diri seseorang. Penggunaan bahasa mencerminkan keperibadian seseorang sama ada bersifat positif ataupun negatif.

Daripada bahasa kiasan yang dibincangkan, jelas sekali membuktikan bahawa bahasa kiasan menyingkap hubungan antara bahasa dengan pemikiran, falsafah, akal budi, dan perlakuan penuturnya. Justeru itu, bahasa kiasan yang digunakan mempunyai kepelbagaian tujuan selain digunakan untuk menjaga aib seseorang, antaranya pengungkapan yang mencetuskan konflik, kekecewaan, perkelahian dan ketidakpuasan hati. Pemahaman terhadap bahasa kiasan dapat dicapai berdasarkan konteks dan kesan konteks yang maksimum. Dengan demikian, TR dan LB dilihat amat berwibawa dalam membantu dan menginterpretasi makna sebenar bahasa kiasan tersebut. Penggunaan bahasa kiasan dalam filem dilihat merupakan satu bentuk penginterpretasian budaya dan bahasa yang terdapat dalam sesebuah masyarakat yang memaparkan ketinggian akal pemikiran dalam mengungkapkan sesuatu. Setiap ujaran yang digunakan dalam dialog merupakan sesuatu penglahiran realiti sebenar dalam masyarakat yang melatari pada masa tersebut.

\section{KESIMPULAN}

Interpretasi makna yang melibatkan kosa ilmu pragmatik terhadap bahasa kiasan dalam filem Melayu terpilih mampu memudahkan tafsiran makna. Bahasa kiasan menerusi ujaran watak yang mengandungi peribahasa mahupun bukan peribahasa dalam kajian ini menjelaskan kepentingan interpretasi makna yang mendalam bagi memastikan hajat komunikatif penutur dalam konflik dapat difahami. Hal ini demikian kerana penggunaan bahasa kiasan dalam mengungkapkan sesuatu konflik dilihat sesuatu yang amat menarik bahkan mencerminkan keperibadian dan ketinggian ilmu masyarakat Melayu. Konflik yang berlaku dalam filem sudah semestinya akan meninggalkan kesan kepada komunikator kerana plot konflik merupakan plot kemuncak cerita yang menentukan keberkesanan sesuatu filem. Bahasa kiasan yang diperoleh dalam kajian ini yang digunakan semasa konflik bukan sahaja sebagai indicator manifestasi kehebatan penggunaan bahasa Melayu, tetapi pemikiran dan keintelektualan yang hendak disampaikan dalam karya seni filem dapat disampaikan kepada penonton khasnya masyarakat Melayu. 
Di samping itu, penggunaan bahasa kiasan dalam filem juga menonjolkan keindahan bahasa Melayu dalam mengungkapkan sesuatu perkara, walhal dalam situasi konflik. Penggunaan bahasa kiasan dalam konflik ini memperlihatkan ketinggian akal budi masyarakat Melayu yang mementingkan hubungan harmoni dalam masyarakat, walaupun wujudnya sesetengah pihak yang berkelakuan negatif. Penggunaan bahasa kiasan juga memperlihatkan wujudnya akal budi positif dan negatif. Akal budi positif merupakan cerminan perilaku yang baik, sopan, santun, berakhlak di samping penjagaan tutur bicara daripada mengatakan sesuatu yang negatif. Akal budi negatif pula merupakan cerminan perilaku yang negatif seperti berkelakuan tidak moral, hasad dengki, iri hati dan dendam, walaupun tutur bicaranya memperlihatkan ketinggian bahasa. Hal ini dapat dilihat pada FSM melalui watak Awang yang mempunyai niat jahat walaupun berkedudukan dan mempunyai tutur bicara yang berkias. Begitu juga halnya dengan watak Panglima Ali dalam FLK. Justeru itu, penggunaan bahasa kiasan dapat mencerminkan keperibadian dan akal budi seseorang sama ada positif mahupun negatif.

\section{RUJUKAN}

Abd. Ganing Laengkang. (2018). Analisis Lakuan Bahasa Terhadap Teks Khutbah Jumaat Negeri Selangor. Jurnal Hal Ehwal Islam dan Warisan Selangor. Bil. 2. No. 1. 2018.

Abdul Basir Awang et, all. (2016). Tetenunan Kinayah Arab dan Kiasan Melayu: Suatu Analisis Kontrastif. Volume 5, Issue 1 2016, e-Academia Journal UiTMT.

Abdullah Hassan \& Ainon Mohd. (2011), Kamus Peribahasa Kontemporari. Edisi Ketiga. Selangor: PTS Professional Publishing Sdn. Bhd.

Aminnudin Saimon \& Zaitul Azma Zainon Hamzah. (2016). Pentafsiran Makna dalam Ujaran Saling Memahami. Jurnal Linguistik, vol. 20 (2) Disember 2016 (033 - 041).

Anida Sarudin. (2010). Aspek Kognitif dalam Pembentukan Simpulan Bahasa Kata Makan. PENDETA - Jurnal Bahasa dan Sastera Melayu.

Black, C. (2003). Speaking with Foked Tongue: A Comparative Study of Metaphor and Metonymy in English and Malay Phraseology. University of Surrey: Department of Linguistic, Cultural \& International Studies. Metaphor \& Symbol. 18 (4). 289 - 310.

Black. C. (2002). Figuration, Lexis and Cultural Resonance: A Corpus Based Study of Malay. Journal of Pragmatics. 10:3, $281-300$.

Carston, R. (2010). Metaphor: Ad Hoc Concepts, Literal Meaning and Mental Images. Proceeding of the Aristotelian Society, 110, $295-321$.

Faziela Abu Bakar dan Nik Rafidah Nik Muhamad Affendi. (2017). Unsur Emosi dalam Novel Komsas. PENDETA - Jurnal Bahasa dan Sastera Melayu.

Hamidah Abdul Wahab dan Wan Robiah Meor Osman. (2009). Unsur Kiasan dalam Wacana Khutbah Jumaat di Malaysia. Kertas Kerja dimajukan dan dibentangkan di Seminar Internasional Pertemuan Linguistik Utara6, Medan. Universiti Sumatera Utara \& Balai Bahasa, Medan.

Hasmidar Hassan \& Jafizah Jaafar (2016). Penginterpretasian Peribahasa dan Hubungannya dengan Kemahiran Berfikir: Analisis Berdasarkan Teori Relevans. Jurnal Bahasa, Jilid 16. Bil. 1 (2016).

Hatta Azad Khan (2014). Teater, Filem dan Pengurusan Seni. Kuala Lumpur: Dewan Bahasa dan Pustaka

Hawiyah Baba \& Nor Hashimah Jalaluddin (2015). Nilai Melayu dalam Simpulan Bahasa: Analisis Pragmatik. Seminar Linguistik Kebangsaan (SLiK2015). Kuala Lumpur: Dewan Bahasa dan Pustaka

Mohd. Aris Anis \& Ahmad Esa (2016). Fungsi dan Peranan Komunikasi Berimplikatur dalam Budaya Masyarakat Melayu Islam. Jurnal Pemikir Pendidikan (2016) 7: 101 - 112.

Mohd. Rasdi Saamah (2011). Alam dan Budaya dalam Bahasa Kiasan Bahasa Semai. Dibentangkan di Seminar Penyelidikan 2011 Zon Timur di IPG Kampus Sultan Mizan, Besut, Terengganu.

Nor Afiqah Wan Mansor \& Nor Hashimah Jalaluddin (2016). Makna Implisit Bahasa Kiasan Melayu: Mempertalikan Komunikasi, Kognisi dan Semantik. Jurnal Komunikasi. Malaysian Journal of Communication. Jilid 32 (1) 2016: 189-206.

Noraini Shahida Ishak \& Maschitah Mansor, M. (2014). Peribahasa: Gambaran Minda Melayu dalam Penciptaan Iklan. Divisyen Bahasa Melayu, CELPAD: UIAM. 
Saripah Banseng dan Rosline Sandai. (2017). Unsur Bahasa Kiasan Metafora dalam Sampi Iban. PENDETA Journal of Malay Language, Education and Literature. Jilid 8. 2017.

Searle, J. R. (1969). Speech Acts: An Essay in the Philosophy of Language. New York: Cambridge University Press.

Siti Zuhaidah Zakeria dan Nik Rafidah Nik Muhamad Affendi. (2017). Konflik dalam Cerita Rakyat dan Kesannya kepada Kanak-Kanak. PENDETA - Jurnal Bahasa dan Sastera Melayu.

Sperber, D. \& Wilson, D. (1995). Relevance Communication and Cognition Second Edition.Cambridge: University Press.

Sperber, D. \& Wilson, D. (1986). Relevance Communication and Cognition. Cambridge: University Press.

Video Compact Disc. Filem Semerah Padi (1956)

Video Compact Disc. Filem Hang Jebat (1961)

Video Compact Disc. Filem Seri Mersing (1961)

Video Compact Disc. Filem Lancang Kuning (1962)

Wong Shia Ho (2014). Penggunaan Simbol dalam Teks Ucapan Tunku Abdul Rahman: Analisis Teori Relevans. Jurnal Bahasa, Jilid 14. Bil. 1 (2014) hlmn. 60 - 91

Yusniza Yaakub dan Noriah Mohamed. (2018). Ungkapan Berimplikatur Sebagai Strategi Kesopanan dalam Warkah Pendeta Za'aba. PENDETA Journal of Malay Language, Education and Literature. Jilid 9. 2018.

Zaitul Azma Zainon Hamzah \& Ahmad Fuad Mat Hassan (2011). Peribahasa Melayu Penelitian Makna dan Nilai. Serdang: Penerbit Universiti Putra Malaysia.

Zaitul Azma Zainon Hamzah \& Ahmad Fuad Mat Hassan (2011). Bahasa dan Pemikiran dalam Peribahasa Melayu. GEMA Online TM Journal of Language Studies, Vol. 11 (3), September 2011.

Zohreh Rasekh Eslami. (2017). Refusal: How to Develop Appropriate Refusal Strategies. Texas A\&M University. $217-236$. 